\title{
Membumikan Laporan Keuangan untuk Penghafal Al-Quran
}

\author{
Puji Wibowo, Akhmad Khizazi, Azas Mabrur \\ Politeknik Keuangan Negara STAN \\ puji.wibowo@pknstan.ac.id
}

Submitted: $31^{\text {st }}$ July 2019. Revised: $11^{\text {th }}$ October 2019. Accepted: $31^{\text {st }}$ October 2019

Key word:

non-profit organization; financial reporting; accounting standard

\section{Kata Kunci}

organisasi nonprofit; laporan keuangan; standar akuntansi

\section{Abstract}

Alquran-based educational institutions are one of the most important supplier of the nation's generation of noble character, love of the motherland, and global outlook. The survival of these educational institutions is determined, among other things, by the organization's sound and transparent financial management. Financial reports are an instrument for educational institutions to evaluate performance and plan activities that are realistic and adaptive to change. Islamic Education Foundation Islamic Boarding School Alquraniyah (YPI-PPA) East Jurangmangu, Pondok Aren, South Tangerang has the responsibility to give birth to the nation's cadres who are polite, love the Koran, and ready to contribute to the wider community. Fostering financial management, especially in preparing financial statements, is crucial for stakeholders who need a guarantee of business continuity from the educational institution. The synergy between students and lecturers at the State Financial Polytechnic STAN has sought to raise awareness for YPI-PPA employees to begin cleaning up in preparing financial reports that are more comprehensive, accountable, and provide full information for decision makers.

\section{Abstrak}

Lembaga pendidikan berbasis Alquran merupakan salah satu ujung tombok pencetak generasi bangsa yang berakhlaq mulia, cinta tanah air, dan berwawasan global. Keberlangsungan hidup lembaga pendidikan tersebut antara lain ditentukan oleh pengelolaan keuangan organisasi yang sehat dan transparan. Laporan keuangan merupakan instrument bagi lembaga pendidikan untuk mengevaluasi kinerja dan menyusun rencana kegiatan yang realistis dan adaptif terhadap perubahan. Yayasan Pendidikan Islam Pondok Pesantrean Alquraniyah (YPI-PPA) Jurangmangu Timur, Pondok Aren, Tangerang Selatan mengemban tanggung jawab untuk melahirkan kader bangsa yang santun, cinta alquran, dan siap berkontribusi pada masyarakat luas. Pembinaan pengelolaan keuangan khususnya dalam penyiapan laporan keuangan menjadi hal krusial bagi para pemangku kepentingan yang membutuhkan adanya jaminan kelangsungan usaha dari lembaga pendidikan tersebut. Sinergi antara mahasiswa dan dosen Politeknik Keuangan Negara STAN telah berupaya menumbuhkan kesadaran bagi para pegawai YPI-PPA untuk mulai berbenah dalam penyiapan laporan keuangan yang lebih komprehensif, akuntabel, dan memberikan informasi utuh bagi para pengambil keputusan. 


\section{PENDAHULUAN}

Dewasa ini kondisi masyarakat di Indonesia sedang mengalami turbulensi sosial seiring dengan maraknya perkembangan teknologi informasi. Mengalirnya berbagai macam informasi baik yang bersifat positif maupun negatif turut memberikan pengaruh besar kepada masyarakat. Dampak yang dirasakan kian nyata adalah memudarnya nilai-nilai sosial dan budi pekerti 'orang timur' yang sejatinya menjadi ciri khas dari masyarakat Indonesia. Sebagian kelompok masyarakat mulai menjadikan berbagai macam tokoh yang disodorkan oleh berbagai media, mulai dari media cetak maupun daring, sebagai idola dan panutan mereka.Tidak sedikit panutan ataupun tokoh yang menjadi panutan tersebut sebenarnya justru membawa masyarakat, khususnya generasi muda, menuju jati diri yang jauh dari yang diharapkan.

Munculnya krisis identitas tersebut sebenarnya mulai dikhawatirkan sejak beberapa tahun silam, khususnya sejak mata pelajaran budi pekerti tidak lagi menjadi materi yang dianggap prioritas. Otoritas pengambil kebijakan beranggapan bahwa budi pekerti dapat dibentuk melalui pendidikan agama oleh orang tua masingmasing sesuai dengan agama dan keyakinannya. Oleh karena itu, pendidikan budi pekerti yang membentuk pribadi dengan akhlak mulia menjadi sebuah kebutuhan.

Yayasan Pendidikan Islam Pondok Pesantren Alquraniyah (YPI-PPA) hadir di tengah-tengah masyarakat yang rindu dengan suasana keluhuran budi pekerti. YPI-PPA adalah sebuah yayasan yang berbadan hukum yang mencetak santri agar dapat membaca Al-Qur'an secara fasih dan benar sesuai dengan ilmu Tajwid, serta mampu melantunkannya sesuai dengan ilmu Nagham dan ilmu Qiro'at yang berlaku. Disamping itu, yayasan ini membekali santrinya dengan pengajian Kitab Kuning dan keterampilan bermasyarakat. Diharapkan dengan bekal tersebut para santri dapat menjadi pribadi yang berkualitas handal dan mampu berkiprah di masyarakat sebagai UstadzUstadzah, Qori-Qori'ah, dan HafidzHafidzah yang menguasai ilmu Sains dan Teknologi, serta berakhlakul karimah.

Dalam rangka menjalankan misi untuk mencerdaskan kehidupan bangsa dengan pendekatan Alquran, YPI-PPA mengembangkan institusi pendidikan mulai dari jenjang taman kanak-kanak (TK) hingga sekolah menengah atas (SMA). Dengan jumlah siswa yang kian bertambah tiap tahunnya, membuktikan bahwa YPIPPA semakin memperoleh tempat di hati masyarakat. Seiring dengan beragamnya 
program kerja dan meningkatnya intensitas kegiatan, pengelolaan keuangan menjadi sebuah isu penting. Tidak bisa dipungkiri going concern sebuah entitas pendidikan antara lain ditentukan oleh seberapa baik entitas tersebut melakukan pengelolaan keuangannya. Kualitas pengelolaan keuangan dapat dinilai dari sebuah laporan keuangan yang merupakan wujud pertanggungjawaban keuangan pada organisasi pendidikan tersebut.

Sitorus, et al. (2013) menjelaskan bahwa dalam yayasan terdapat prinsip akuntabilitas dan transparansi yang wajib dijadikan acuan utama oleh tiap-tiap yayasan dalam menyusun kebijakan dan prosedur penerapan prinsip akuntabilitas dan transparansi. Murdayanti dan Puruwita (2019) menyatakan bahwa pesantren pada umumnya sudah membuat sistem anggaran yang baik namun belum sesuai dengan standar akuntansi keuangan yang berlaku untuk organisasi nirlaba dalam penyusunan laporan keuangannya. Berkenaan dengan persoalan Yayasan, Usman (2013) mengungkapkan bahwa beberapa masalah yang dihadapi pesantren antara lain disebabkan oleh adanya keterbatasan kemampuan pengelolanya antara lain sarana dan prasarana penunjang yang terlihat masih kurang memadai, keterbatasan sumber daya manusia dalam bidang manajemen kelembagaan serta bidang-bidang lain, manajemen kelembagaan pesantren masih dikelola secara tradisional, kebutuhan keuangan selalu menjadi kendala, serta kurikulum yang berorientasi life skills santri dan masyarakat.

Sebagaimana dinyatakan dalam Pernyataan Standar Akuntansi Keuangan (PSAK) Nomor 45 tentang tentang Pelaporan Keuangan Organisasi Nirlaba, karakteristik organisasi nirlaba berbeda dengan organisasi bisnis.Perbedaan utama yang mendasar terletak pada cara organisasi memperoleh sumber daya yang dibutuhkan untuk melakukan berbagai aktivitas operasinya. Organisasi nirlaba memperoleh sumber daya dari sumbangan para anggota dan para penyumbang lain yang tidak mengharapkan imbalan apapun dari organisasi tersebut.Sebagai akibat dari karakteristik tersebut, dalam organisasi nirlaba timbul transaksi tertentu yang jarang atau bahkan tidak pernah terjadi dalam organisasi bisnis, misalnya penerimaan sumbangan. Namun demikian dalam praktik organisasi nirlaba sering tampil dalam berbagai bentuk sehingga seringkali sulit dibedakan dengan organisasi bisnis padaumumnya.

Pada beberapa bentuk organisasi nirlaba, meskipun tidak ada kepemilikan, organisasi tersebut mendanai kebutuhan 
modalnya dari utang dan kebutuhan operasinya dari pendapatan atas jasa yang diberikan kepada publik. Akibatnya, pengukuran jumlah, saat, dan kepastian aliran pemasukan kas menjadi ukuran kinerja penting bagi para pengguna laporan keuangan organisasi tersebut, seperti kreditur dan pemasok dana lainnya. Oleh karena itu, penyajian laporan keuangan bagi YPI-PPA yang kredibel dan transparan merupakan sebuah prioritas bagi pengembangan yayasan ini di masa yang akan datang.

Berdasarkan hasil pengamatan dan wawancara dengan beberapa pegawai YPIPPA, terdapat beberapa isu penting. Masalah utama yang dihadapi oleh YPIPPA terkait dengan penyiapan laporan keuangan adalah: kapasitas sumber daya manusia, fasilitas pendukung, dan ketiadaan daftar inventaris aset yang memadai. Faktor sumber daya manusia menjadi salah satu kendala karena pegawai yang melaksanakan tugas pengelolaan keuangan Yayasan sebagian besar berlatar belakang pendidikan agama. Sebagian besar dari pegawai merupakan para penghafal alquran yang tidak pernah secara khusus memperoleh pendidikan maupun pelatihan akuntansi. Hanya terdapat satu pegawai.

Fasilitas pendukung menjadi persoalan tersendiri karena dalam praktiknya selama ini, pembukuan atas transaksi keuangan Yayasan yang diinput di dalam Microsoft excel, bukan dalam bentuk aplikasi yang terintegrasi. Kondisi ini menyebabkan lambannya penyiapan laporan keuangan. Data yang disajikan juga berpotensi mengandung salah saji karena ketiadaan proses check and balances yang biasanya divalidasi di dalam sistem aplikasi pembukuan.

Daftar inventaris aset menjadi persoalan krusial karena hingga saat ini pihak Yayasan tidak bisa membedakan jenis dan kuantitas aset mana saja yang merupakan milik Yayasan sebagai badan hokum atau pun milik pribadi pimpinan Yayasan. Tidak tersedianya daftar inventaris aset menyebabkan Yayasan belum bisa menyusun neraca atau laporan posisi keuangan.

\section{METODE}

Dalam rangka membantu YPI-PPA untuk menyelesaikan permasalahan di atas, tim pengabdian masyarakat Politeknik Keuangan Negara STAN (PKN STAN) menyusun serangkaian program. Kegiatan tersebut merupakan pengabdian masyarakat yang terintegrasi dengan Kuliah Kerja Mahasiswa (KKM). Tim pengabdian masyarakat (pengmas) terdiri dari dua orang dosen dari Program Diploma III Akuntansi. Adapun KKM 
dilaksankaan oleh sepuluh orang mahasiswa lintas jurusan, mewakili empat jurusan di PKN STAN, yaitu akuntansi, manajemen keuangan, pajak, dan kepabeanan. Mahasiswa yang mengikuti KKM adalah mahasiswa aktif pada semester IV (Diploma III) dan semester VIII (Diploma IV).

Kegiatan pengmas terintegrasi KKM tersebut dilaksanakan pada tanggal 22-26 Juli 2019 mulai pukul 08.00 WIB s.d. 15.00 WIB bertempat di YPI-PPA. Kegiatan utama berupa diseminasi atau pun pelatihan laporan keuangan dan dirancang dengan menggunakan metode andragogi. Metode ini ditempuh karena peserta pelatihan merupakan orang dewasa.

Salah satu teori andragogi yang popular adalah teori andragogi Carl Roger dan dikenal dengan pendidikan orang dewasa humanistic (Irmawan 2015). Asumsi dasar pemikiran roger adalah sebagai berikut : Pertama, ada gagasan bahwa insan manusia adalah aktif dan bebas yaitu pada dasarnya manusia itu baik. Kedua, ada gagasan bahwa manusia memiliki dorongan dari dalam, yaitu motivasi indtrinsik dorongan untuk mengembangkan diri. Ketiga, ada gagasan yang di sinilah terletak potensi manusia, di mana kegairahan terganatung pada lingkungannya (Mathias Finger dan Jose Manuel Asun, 2004:78).
Tahapan yang dilakukan adalah dengan menggunakan pendekatan yang berpusat pada masalah. Menurut Kusnadi, et al dalam Irmawan (2015) program belajar yang berpusat pada masalah, mengarahkan pengalaman belajar pada masalah yang dihadapi oleh warga belajar dalam kehidupan sehari-hari, dengan maksud untuk memperlihatkan kepada mereka bahwa pengetahuan yang diperoleh erat kaitannya dengan kegunaan dan masalah yang dihadapinya.

Berdasarkan pemahaman tersebut di atas, pelatihan yang dilakukan meliputi beberapa tahapan sebagai berikut:

Dua hari pertama difokuskan untuk memberikan pembekalan terkait pentingnya menyusun laporan keuangan yang baik dan kegunaanya serta memberikan pengetahun dasar teknik untuk menyusun laporan keuangan dan membaca informasi laporan keuangan. Selain itu, pada hari tersebut juga disisipi materi inventarisasi asset untuk menunjang penyusunan laporan posisi keuangan. Pada hari ketiga, para staf dan bendahara umum diasistensi untuk mempraktikkan teknik pencatatan transaksi keuangan yang sering dilakukan oleh yayasan dan juga ditambahkan materi terkait pengetahuan perpajakan bagi yayasan dan dana-dana bantuan yang mengalir ke yayasan serta tata cara pelaporannya. 


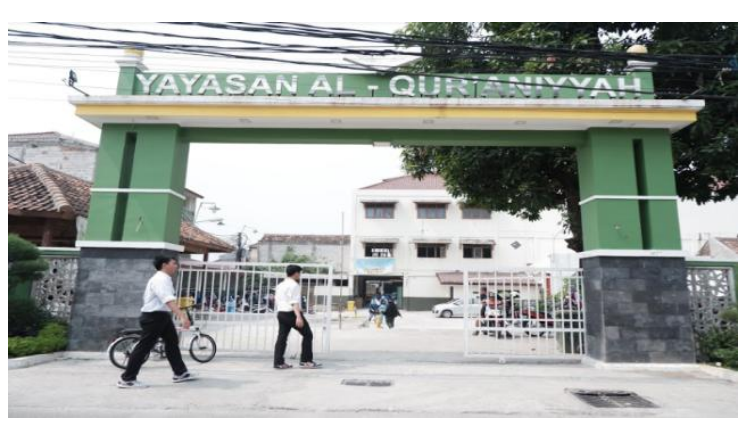

Gambar 1. Pintu Utama YPI-PPA

\section{HASIL DAN PEMBAHASAN}

\section{Tahapan Kegiatan}

a. Perkenalan dan pendekatan

Pada tahap ini, tim pengmas beserta para mahasiswa menjumpai pimpinan YPI-PPA yakni KH Dr Muhammad Shobron Zayyan, SQ, MA. Pendekatan kepada pimpinan dimaksudkan untuk memberikan penjelasan mengenai program yang dilakukan serta berbagi pengalaman terkait pengelolaan keuangan organisasi non-profit. Berdasarkan penuturan dari 'Abi', panggilan akrab dari pimpinan YPI-PPA, pegawai yang menangani pengelolaan keuangan Yayasan termasuk yang menyusun laporan keuangan sebagian besar berasal dari lulusan pondok pesantren Alquraniyah yang berada di bawah naungan YPI-PPA.

Para pegawai merupakan para penghafal alquran yang kesehariannya juga bertugas untuk mengajarkan alquran dan beberapa mata pelajaran agama. Oleh karena itu, 'Abi' sangat berharap kehadiran tim pengmas PKN STAN beserta para mahasiswa dapat memberikan dorongan, motivasi, sekaligus pencerahan terkait penyusunan laporan keuangan yang lebih berkualitas dengan menggunakan standar akuntansi yang dapat diterima secara umum.

Selama ini, laporan keuangan yang disusun hanyalah berupa aliran masuk dan aliran keluar uang tunai pada masing-masing tingkatan sekolah, yaitu laporan keuangan Taman Kanak-Kanak, laporan keuangan Sekolah Dasar, laporan keuangan Sekolah Menengah Pertama, dan laporan keuangan Sekolah Menengah Atas. Meskipun bertajuk laporan keuangan, namun pada hakikatnya laporan yang dihasilkan baru sebatas laporan arus kas.

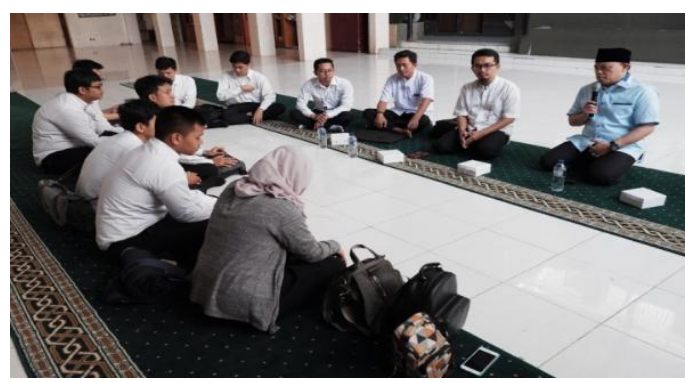

Gambar 2. Mendengarkan sambutan pimpinan YPI-PPA 


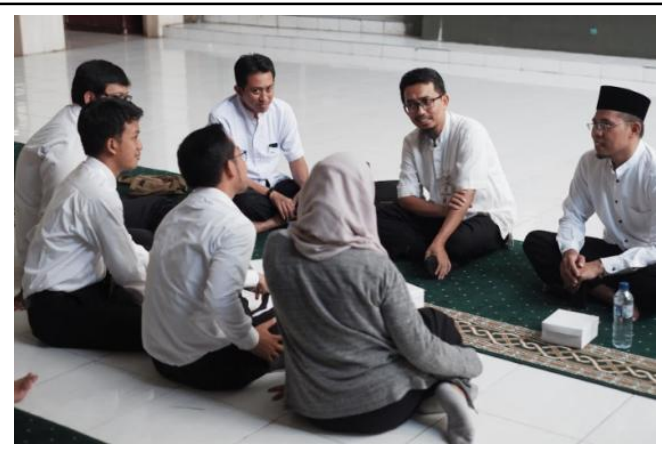

Gambar 3. Berdiskusi dengan Ustadz Halimi, Kepala Sekolah SMA Alquraniyah

b. Sharing pengalaman

Sharing pengalaman dimaksudkan untuk mengetahui latar belakang pendidikan dan jenis pekerjaan masing-masing pekerja YPI-PPA yang mengikuti pelatihan. Para pegawai YPI-PPA yang hadir pada sesi sharing yang dilaksanakan pada tanggal 22 Juli 2019 pukul 13.00 s.d. 15.00 terdiri dari 12 staf dan 1 orang bendahara umum. Penyusunan laporan arus kas Yayasan disusun oleh bendahara umum berdasarkan data dari para pegawai di tiap-tiap sekolah yang berada di bawah YPI-PPA. Di dalam sesi ini dipaparkan pengenalan konsep akuntansi organisasi nirlaba, terutama berasal dari Pernyataan Standar Akuntansi Keuangan (PSAK) Nomor 45. Mengingat materi PSAK merupakan materi yang cukup berat bagi orang umum, maka pendekatan yang dilakukan adalah dengan bincang-bincang santai dan menggunakan pilihan kata yang sederhana agar mudah dicerna. Disamping itu, dibangung proses dialog interaktif karena orang dewasa lebih suka diajak berdiskusi dibandingkan dengan hanya mendengarkan materi secara satu arah.

Berdasarkan hasil sharing, diketahui para pegawai belum sepenuhnya memahami konsep akrual di dalam penyusunan laporan keuangan.

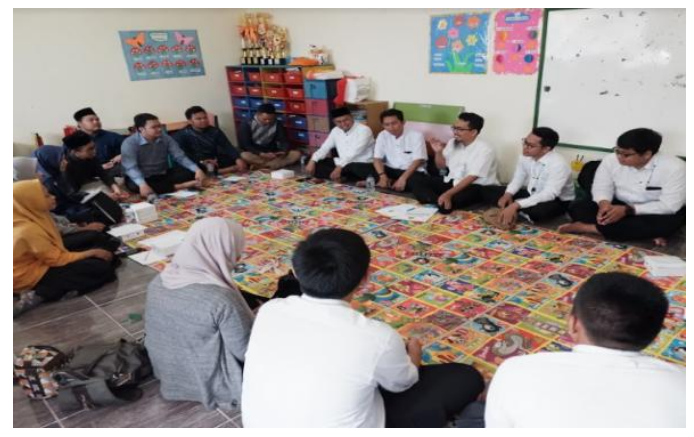

Gambar 4. Sesi sharing dengan suasana santai

$$
\text { Setelah mendengarkan }
$$
penjelasan para pegawai YPI-PPA, tim pengmas mulai melakukan pemaparan awal dengan materi akuntansi Yayasan. Di dalam sesi ini dijelaskan peran penting akuntansi dalam memberikan informasi bagi para pemangku kepentingan Yayasan. Disamping itu, ditekankan juga, YPI-PPA harus mulai berbenah diri untuk mempelajari dan 
menerapkan basis akrual. Setelah penyampaian materi, dibuka kembali sesi dialog untuk menggali kembali isu-isu penting terkait penyusunan laporan keuangan. Dalam sesi ini, peserta diberikan hand-out untuk dipelajari sebagai persiapan pelatihan pada hari kedua.

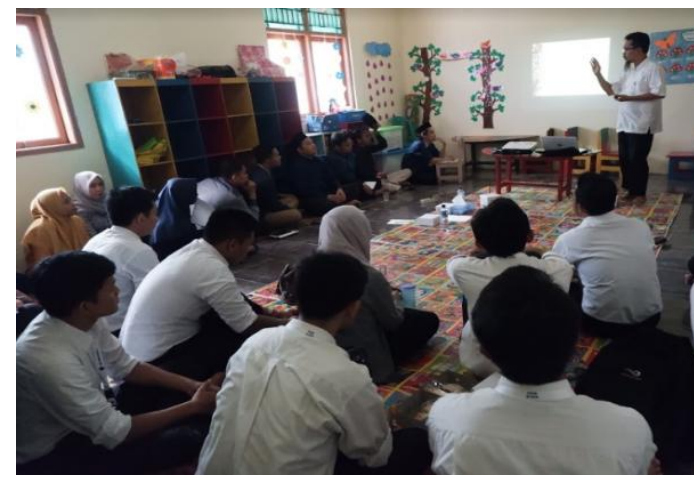

Gambar 5. Materi awal disampaikan di ruang kelas Taman KanakKanak

c. Pelatihan

Program utama kegiatan pengmas adalah memberikan pelatihan dengan menggunakan teori andragogi dan pendekatan yang berpusat pada masalah. Dalam tahapan ini, dibangun proses komunikasi antara tim pengmas, mahasiswa dan para peserta pelatihan. Pelaksanaan pelatihan secara full day dilaksanakan pada hari kedua, mulai pukul 08.00 s.d. 15.00 WIB. Sebelum sesi pemaparan materi, para pegawai diminta menyampaikan output pekerjaan mereka selama ini yang berupa laporan arus kas versi sederhana.

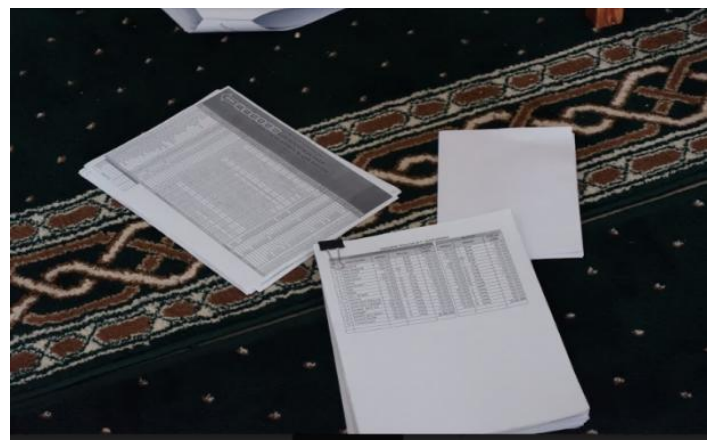

Gambar 6.Output pekerjaan terkait pengelolaan keuangan yayasan

Tim pengmas menjelaskan bahwa laporan keuangan Yayasan seyogianya tidak hanya berupa laporan arus kas, namun juga berupa laporan aktivitas dan laporan posisi keuangan atau neraca. Pada hari kedua ini, peserta pelatihan diberikan materi mengenai konsep dasar akuntansi. Materi konsep dasar akuntansi meliputi pengenalan akun pendapatan, beban, aset, liabilitas, dan ekuitas, termasuk di dalamnya pengenalan mengenai konsep debit dan kredit. Konsep akrual kembali ditekankan agar para pegawai mulai berfikir mengenai pentingnya konsep akrual dalam penyusunan laporan keuangan. Materi tersebut disampaikan oleh para mahasiswa secara bergiliran. Pelatihan pada hari kedua ini dilaksanakan di salah satu 
bangunan pesantren yang dikenal sebagai masjid untuk program tahfidz alquran.

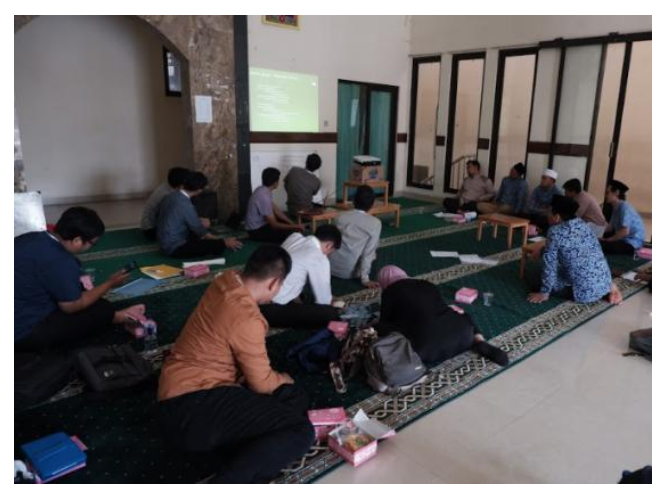

Gambar 7. Penyampaian materi oleh mahasiswa

Materi yang tidak kalah pentingnya untuk disampaikan adalah mengenai inventarisasi aset.

Persoalan utama Yayasan ini adalah belum adanya daftar aset yang komprehensif menggambarkan kekayaan YPI-PPA sebagai sebuah badan hukum. Disamping itu, Yayasan juga belum membuat daftar inventaris barang di tiap ruangan maupun menyusun kodefikasi barang. Oleh karena itu, persoalan aset dibahas secara intensif setelah sesi pemaparan konsep dasar akuntansi.

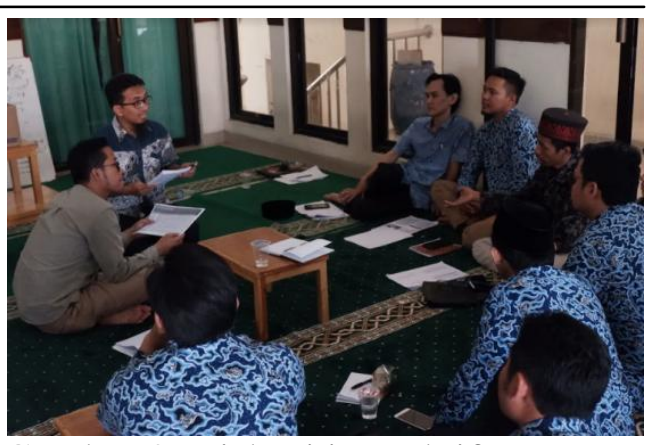

Gambar 8. Diskusi interaktif

d. Tutorial dan simulasi

Pada hari ketiga, mahasiswa menyusun aplikasi sederhana berbasis Microsoft excel. Aplikasi ini diharapkan dapat memberikan kemudahan bagi para pegawai Yayasan untuk mencatat transaksi. Di dalam aplikasi sederhana ini, setiap transaksi yang dicatat di dalam sheet 'Jurnal' akan secara otomatis menambah saldo pada laporan keuangan. Beberapa hal penting terkait aplikasi sederhana berbasis excel tersebut antara lain meliputi menu:

1) Daftar akun

Daftar akun terdiri dari seluruh akun yang distandardisasi untuk digunakan dalam pencatatan transaksi aset, liabilitas, ekuitas, pendapatan, dan beban. 


\begin{tabular}{|c|c|c|}
\hline NAMA AKUN & KODE & GABUNGAN \\
\hline Kas dan Setara Kas & 101 & 101 Kas dan Setara Kas \\
\hline Piutang luran Santri & 102 & 102 Piutang luran Santri \\
\hline Perlengkapan & 103 & 103 Perlengkapan \\
\hline Piutang Lain-lain & 104 & 104 Piutang Lain-lain \\
\hline Peralatan & 111 & 111 Peralatan \\
\hline Tanah & 112 & 112 Tanah \\
\hline Bangunan & 113 & 113 Bangunan \\
\hline Aset Tidak Lancar Lainnya & 121 & 121 Aset Tidak Lancar Lainnya \\
\hline Konstruksi Dalam Pengejaan & 122 & 122 Konstruksi Dalam Pengerjaan \\
\hline Aset Lain-lain & 123 & 123 Aset Lain-lain \\
\hline Hutang Pihak ke- 3 & 201 & 201 Hutang Pihak ke-3 \\
\hline Pendapatan Diterima Dimuka & 202 & 202 Pendapatan Diterima Dimuka \\
\hline Hutang Lain-lain & 203 & 203 Hutang Lain-lain \\
\hline Bagian Lancar Hutang Jangka Panjang & 204 & 204 Bagian Lancar Hutang Jangka Panjang \\
\hline Hutang Jangka Panjang-BANK & 211 & 211 Hutang Jangka Panjang-BANK \\
\hline Hutang Jangka Panjang-Pembiayaan & 212 & 212 Hutang Jangka Panjang-Pembiayaan \\
\hline Aset Neto & 301 & 301 Aset Neto \\
\hline Penerimaan luran SPP & 400 & 400 Penerimaan luran SPP \\
\hline Penerimaan luran Makan & 401 & 401 Penerimaan luran Makan \\
\hline & & \\
\hline
\end{tabular}

Gambar 9. Daftar Akun

Para mahasiswa menjelaskan fungsi dari masing-masing akun beserta memperagakan pencatatan transaksinya.

2) Jurnal

$$
\text { Menu 'Jurnal' digunakan }
$$
sebagai 'sheet' utama untuk mencatat segala transaksi maupun kejadian yang berdampak terhadap keuangan Yayasan. Peserta pelatihan juga diberikan kesempatan untuk melakukan input data sendiri sesuai data riil yang dihadapi.

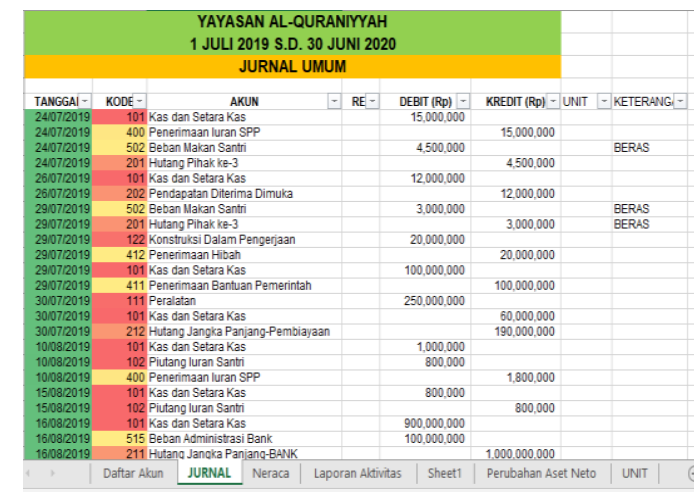

Gambar 10. Simulasi Ayat Jurnal
3) Neraca

Menu 'Neraca' digunakan untuk menampung saldo akun neraca. Tim pengmas menjelaskan bahwa neraca Yayasan belum bisa disusun secara utuh apabila belum YPI-PPA belum melakukan inventarisasi dan penilaian asetnya. Menu 'Neraca' di sini dapat dimanfaatkan untuk memunculkan saldo awal aset Yayasan yang sudah diketahui nilainya. Neraca merupakan laporan keuangan yang penting untuk segera disiapkan oleh Yayasan. Neraca dapat memberikan gambaran mengenai posisi utang-piutang Yayasan. Oleh karena itu, Yayasan dapat mengetahui kapan waktunya Yayasan perlu mengalokasikan dana dalam jumlah besar untuk membayar hutang. Disamping itu, Yayasan juga dapat mengetahui secara real-time posisi piutang yang sebagian besar berasal dari piutang SPP. 


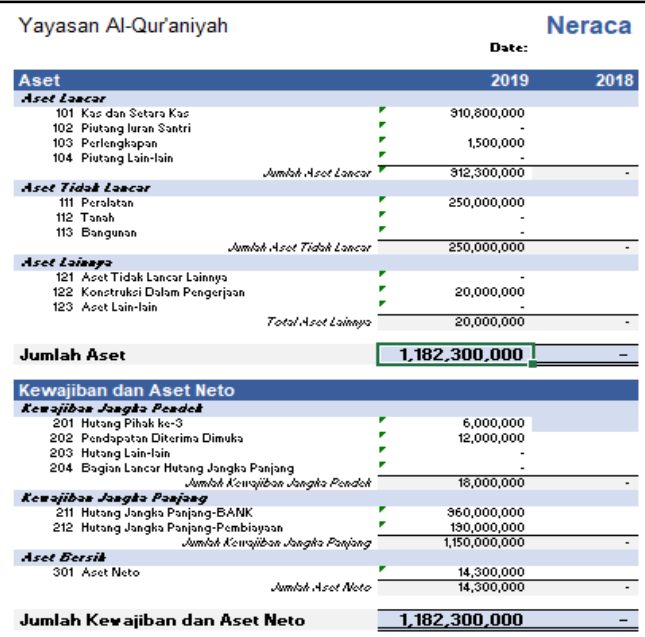

Gambar 11. Contoh Simulasi Neraca

4) Laporan Aktivitas

$$
\text { Menu 'Laporan Aktivitas' }
$$

dapat menunjukkan gambaran kinerja

Yayasan. Disampaikan kepada peserta pelatihan bahwa apabila transaksi harian Yayasan telah menggunakan menu 'Jurnal', maka laporan aktivitas Yayasan dapat setiap saat tersaji. Hal ini penting untuk memberikan potret kinerja keuangan Yayasan kepada pengambil keputusan di YPI-PPA. Laporan aktivitas diatur di dalam PSAK 45. Sesuai dengan exposure draft ISAK 35 yang mengatur pelaporan keuangan organisasi non-profit, istilah laporan aktivitas diganti dengan nomenklatur 'laporan penghasilan komprehensif'.

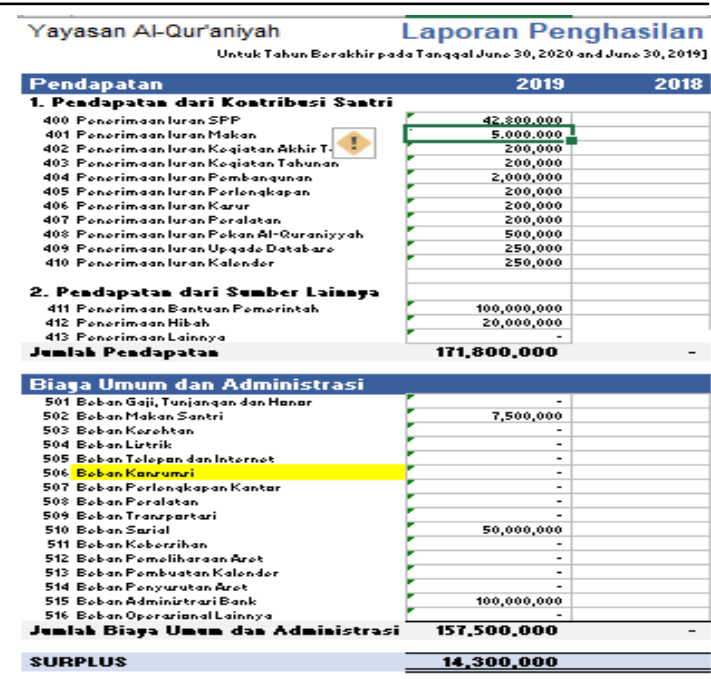

Gambar 12 Simulasi Laporan Aktivitas (Laporan Penghasilan)

\section{Hasil Kegiatan}

Hasil kegiatan pengabdian masyarakat yang terintegrasi dengan KKM ini diharapkan dapat meningkatkan literasi keuangan para pegawai Yayasan yang sebagian besar merupakan para penghafal alquran. Konsep laporan keuangan yang selama ini dianggap kurang membumi, diharapkan dapat mulai dipahami oleh seluruh pegawai yang terlibat dalam pengelolaan keuangan. Program ini diharapkan dapat pula membantu YPIPPA untuk menyusun laporan keuangan secara lebih lengkap dengan kualitas yang baik. Dalam jangka pendek, diharapkan pegawai mulai menggunakan aplikasi sederhana berbasis excel dalam mencatat transaksi harian. Apabila ini dilakukan, Yayasan tidak hanya menghasilkan laporan arus 
kas tapi juga dapat menyiapkan laporan aktivitas atau laporan penghasilan.

\section{SIMPULAN}

Kondisi yang dijumpai pada YPIPPA seperti persoalan SDM merupakan kasus yang banyak ditemui di beberapa tempat sebagaimana ditemukan pula oleh Usman (2013). YPI-PPA mempunyai peluang untuk berkembang dalam hal pengelolaan keuangan apabila memperoleh pendampingan yang efektif dari lembaga pendidikan seperti PKN STAN. Pegawai YPI-PPA yang sebagian besar merupakan penghafal alquran sesungguhnya merupakan modal besar. Seperti diketahui bahwa para penghafal alquran memiliki daya ingat yang tajam. Oleh karena itu, para penghafal alquran tersebut diharapkan dapat cepat menyerap materi baru yang disampaikan oleh para trainer.

Pemanfaatan teknologi merupakan hal yang tidak bisa ditawar lagi. YPI-PPA dapat mulai memanfaatkan teknologi dengan membiasakan diri mencatat transaksi di dalam sebuah aplikasi yang real-time on-line. Aplikasi sederhana yang disusun oleh mahasiswa PKN STAN dapat dijadikan sebagai jembatan menuju pemanfaatan teknologi keuangan secara lebih luas.

Pencapaian tujuan program dapat terpenuhi apabila dilakukan pembinaan secara berkelanjutan. Program ini selanjutnya dapat ditindaklanjuti dengan program pengmas jangka panjang dengan melibatkan lebih banyak dosen dan mahasiswa. Program ini tidak hanya bermanfaat untuk YPI-PPA, tapi juga untuk Yayasan sejenis di wilayah Jurangmangu Timur dan Jurangmangu Barat, dua daerah yang berdekatan dengan kampus PKN STAN. Disamping itu, menu pelatihan dapat ditambahkan dengan materi pengenalan digital accounting. Saat ini, telah tersedia aplikasi untuk pondok pesantren. Untuk itu, pelatihan terkait aplikasi pondok pesantren merupakan peluang bagi PKN STAN untuk menambah kontribusinya kepada masyarakat sekitar khususnya Yayasan yang menaungi pondok pesantren.

\section{DAFTAR PUSTAKA}

Murdayanti, Y., \& Puruwita, D. (2019). Kompetensi Sdm Keuangan dan Akuntabilitas Pesantren. Jurnal Akuntansi, Ekonomi dan Manajemen Bisnis| e-ISSN: 25489836, 7(1), 19-29.

Sitorus, D. C., Nasution, B., \& Windha, W. (2013). Prinsip Akuntabilitas dan Transparansi Yayasan dalam Rangka Mencegah Praktik Pencucian Uang (Money 
Laundering). TRANSPARENCY, 1(

$1)$.

Usman, M. I. (2013). Pesantren Sebagai

Lembaga Pendidikan Islam (Sejarah

Lahir, Sistem Pendidikan, Dan

Perkembangannya Masa

Kini). Jurnal al-Hikmah, 14(1),

127-146.

Irmawan, E. (2015). Implementasi Teori

Andragogi dalam Pembelajaran

Pelatihan di Lembaga Kursus dan

Pelatihan (LKP) Fennyke. Jurnal

Elektronik Mahasiswa Pend. Luar

Sekolah-S1, 4(5) 